\title{
Environmental assessment of heavy metal pollution of Diyala River within Baghdad City
}

\author{
Safaa Nasser Hassan Al-Hussaini ${ }^{1}$ · Abdul Hameed M. Jawad Al-Obaidy ${ }^{2}$. Athmar Abdul Majeed Al-Mashhady ${ }^{2}$
}

Received: 25 October 2017 / Accepted: 10 April 2018 / Published online: 24 May 2018

(c) The Author(s) 2018

\begin{abstract}
Water quality index (WQI), pollution index (PI), and metal index (MI) were applied in the last reach of Diyala River, Baghdad, Iraq with regard to ten heavy metals ( $\mathrm{Cd}, \mathrm{Cr}, \mathrm{Cu}, \mathrm{Ni}, \mathrm{Pb}, \mathrm{Mn}, \mathrm{Fe}, \mathrm{Zn}, \mathrm{Ag}$, and $\mathrm{Cn}$ ). These indices were applied to historical data along with the data obtained from the present study in order to acquire a historical heavy metal assessment of the river reach. The results of WQI showed that the water quality of the reach of interest declined from excellent in the year of 1999 to unsuitable in 2007 then good in 2008 to unsuitable once again in the years of 2009-2015. The PI indicated that $\mathrm{Cd}, \mathrm{Cr}$, and $\mathrm{Pb}$ were the most affecting elements all over the years. The MI was found to be a threshold of warning during all years but with different levels. The impact of Al-Rustimiyah Wastewater Treatment Plants (WWTPs) on the water quality was evident due to the lack of heavy metal treatment units within the plants. It is recommended to add such units to the WWTPs and to reduce the local electricity generators that contribute with great amounts of contaminants.
\end{abstract}

Keywords Water quality index $\cdot$ Pollution index $\cdot$ Metal index $\cdot$ Heavy metals $\cdot$ Diyala River

\section{Introduction}

One of the worldwide problems regarding pollution of aquatic environment is the accumulation of heavy metals, due to their toxic effect on the living being (Mac-Farlane et al. 2006). The increased population and the expanded economic activities would lead to various uses of water and by that rise the stress in terms of water quality (Chougule et al. 2009).

The water quality of any water body is affected by its sources and supplies in terms of their quality and quantity (Alobaidy et al. 2010), in which heavy metals mostly come from anthropogenic activities (Akoto et al. 2008; Shakir et al. 2016).

Water quality indices are valuable tools used in demonstrating the ecological factors' effect on water quality (Ewaid and Abed 2017). It integrates multiple water quality parameter data into a single number that rates the health of

Safaa Nasser Hassan Al-Hussaini

eng.safa@uomustansiriyah.edu.iq; eng.safa74@yahoo.com

1 Environmental Engineering Department, College of Engineering, Mustansiriyah University, Baghdad, Iraq

2 Environmental Research Center, University of Technology, Baghdad, Iraq the ecosystem. This number justifies the water quality into classes varying from excellent to very poor. It can easily be interpreted and understood by political decision-makers, non-technical water managers, and the public (Al-Saboonchi et al. 2011). Several water quality indices have been developed and applied around the world (Prasad and Kumari 2008; Reza and Singh 2010; Manoj et al. 2012; Dede et al. 2013); they differ in the way of translating the values of the parameters (Lumb et al. 2011; Abbasi and Abbasi 2012).

Iraqi aquatic environment is seriously contaminated with heavy metals (Al-Haidarey et al. 2010; Al-Obaidy et al. 2016a). Diyala River, being one of the Tigris River tributaries, was proved to be one of the most polluted rivers in Iraq (Mohammed 1985, 1999; Musa 2009; Al-Anbari and Jumaa 2010; Al-Ghabban 2010; Al-Sudani 2014; Al-Samawi and Al-Hussaini 2015, 2016a, b; Al-Hussaini 2016; Al-Hussaini and Al-Samawi 2017), especially at its last part where the raw and treated effluents of Al-Rustimiyah wastewater treatment plants (WWTPs) discharge into it before its confluence with Tigris River in about $15 \mathrm{~km}$. Al-Rustimiyah WWTP is the oldest sewage network in Iraq, in which third of Baghdad population are served (Shakir et al. 2017).

The objectives of this research study were to evaluate the historical changes in the heavy metals' concentration at the last reach of Diyala River before its confluence with Tigris 
River and its effect on the environmental assessment of the river reach. This is done by calculating pollution indices of heavy metal for previous data and comparing them with that of the present study.

\section{Materials and methods}

\section{The case study}

Previously, $11.3 \%$ of Tigris River's total water income was contributed by Diyala River (Al-Shhrbly 1986). During the last few decades, Diyala River was continually polluted with different sources along its path, having the last part as the most contaminated.

The river reach under investigation was taken opposite Al-Rustimiyah WWTPs about $15 \mathrm{~km}$ before its confluence with Tigris River. The reach was $7 \mathrm{~km}$ in length, and was divided into nine sites having the first site upstream from all the effluents of the WWTPs into the river while the other eight sites were selected according to the points of discharge into the river. Figure 1 illustrates the map of the study area and the sampling sites. The coordinates of each location along with its description is shown in Table 1.
Fig. 1 The study area. Reproduced with Permission from Image (2017)

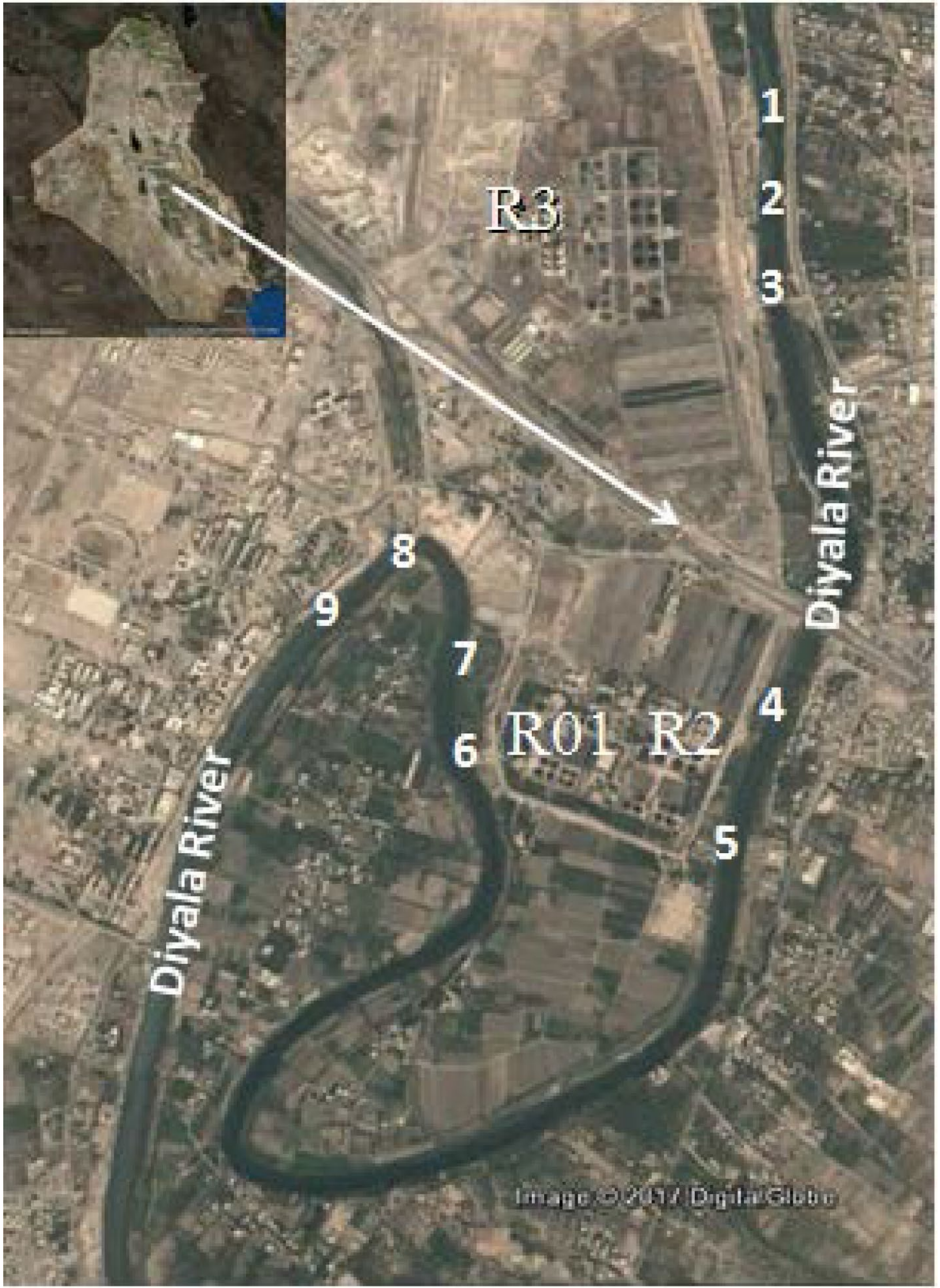


Table 1 Coordinates and description of sampling sites

\begin{tabular}{llll}
\hline Site no. & Description & Longitude & Latitude \\
\hline 1 & Upstream point & $44^{\circ} 32^{\prime} 16.66^{\prime \prime} \mathrm{E}$ & $33^{\circ} 17^{\prime} 31.77^{\prime \prime} \mathrm{N}$ \\
2 & Bypass R3 point & $44^{\circ} 32^{\prime} 16.42^{\prime \prime} \mathrm{E}$ & $33^{\circ} 17^{\prime} 29.18^{\prime \prime} \mathrm{N}$ \\
3 & Outfall R3 point & $44^{\circ} 32^{\prime} 15.95^{\prime \prime} \mathrm{E}$ & $33^{\circ} 17^{\prime} 19.33^{\prime \prime} \mathrm{N}$ \\
4 & Bypass R2 point & $44^{\circ} 32^{\prime} 16.21^{\prime \prime} \mathrm{E}$ & $33^{\circ} 16^{\prime} 27.87^{\prime \prime} \mathrm{N}$ \\
5 & Outfall R2 point & $44^{\circ} 32^{\prime} 2.08^{\prime \prime} \mathrm{E}$ & $33^{\circ} 16^{\prime} 16.32^{\prime \prime} \mathrm{N}$ \\
6 & Outfall R01 point & $44^{\circ} 31^{\prime} 42.68^{\prime \prime} \mathrm{E}$ & $33^{\circ} 16^{\prime} 25.83^{\prime \prime} \mathrm{N}$ \\
7 & Bypass R01 point & $44^{\circ} 31^{\prime} 43.00^{\prime \prime} \mathrm{E}$ & $33^{\circ} 16^{\prime} 39.04^{\prime \prime} \mathrm{N}$ \\
8 & Army channel point & $44^{\circ} 31^{\prime} 36.55^{\prime \prime} \mathrm{E}$ & $33^{\circ} 16^{\prime} 47.68^{\prime \prime} \mathrm{N}$ \\
9 & Downstream point & $44^{\circ} 31^{\prime} 34.23^{\prime \prime} \mathrm{E}$ & $33^{\circ} 16^{\prime} 46.71^{\prime \prime} \mathrm{N}$ \\
\hline
\end{tabular}

\section{Samples collection}

Historical water quality data of heavy metals related to the river reach of interest were collected in the years 1999 (Mohammed 1999), 2007 (Al-Ghabban 2010), 2008 (Musa 2009), 2009 (Al-Anbari and Jumaa 2010), and 2013-2014 (Al-Sudani 2014).

For the present study, in order to cover all seasonal variations in the study area, water samples were collected from the nine sites for a whole year starting from April 2014 to March 2015. The samples were collected at about $15 \mathrm{~cm}$ depth of water in pre-rinsed, with de-ionized water, polypropylene bottles. The samples were refrigerated at $4{ }^{\circ} \mathrm{C}$ until reaching the laboratory where the collected samples were filtered (Whatman $0.45 \mu \mathrm{m}$ ) and acidified with nitric acid in order to reach a $\mathrm{pH}$ below 2.0. That is done to minimize precipitation and adsorption on container walls (Abdulla 2013).

\section{Samples analysis}

The collected samples were analyzed for the heavy metals concentrations $(\mathrm{Cd}, \mathrm{Cr}, \mathrm{Cu}, \mathrm{Ni}, \mathrm{Mn}, \mathrm{Pb}, \mathrm{Fe}, \mathrm{Zn}$, and $\mathrm{Ag})$ by the atomic absorption spectroscopy in the laboratories of the Environmental Research Center, University of Technology, Baghdad, Iraq. They were conducted according to the Standard Method for Examination of Water and Wastewater (APHA 2012).

\section{Water quality indices}

Three types of indices are chosen in this study according to the availability of data: the water quality index (WQI), pollution index (PI), and metal index (MI). The calculations and evaluations of the selected indices are shown in Table 2.

The WQI, in this study, is determined with regard to the heavy metal concentrations by using the weighted arithmetic index method. All the measured parameters contribute in the final value of the WQI. The PI is usually based on the concentration of the individual metal, which means that each metal has its own PI value. The MI evaluates the total trend of metals in the study area, and by that summarizes the status of the study area by one value; the higher the MI value, the worse is the water quality. The standard values for the present study, Table 3, are taken from the Iraqi stream standard according to the criteria of Iraqi legislation of water sources preservation system number 2 (A-1) dated 2001(Ministry of Environment 2001).

\section{Results and discussion}

Table 4 illustrates the statistical analysis of the measured parameters. The three indices were applied to the obtained data in order to display the historical heavy metal water quality of Diyala River. Figure 2 shows the WQI of heavy metal for Diyala Rive throughout the years, while Table 5 reveals the historical evaluation of the WQI. Details of the WQI for the nine sites taken in this study are illustrated in Table 6,

Table 2 The calculations and evaluations of the selected indices

\begin{tabular}{|c|c|c|c|}
\hline Index & Parameters & Evaluation & Ref. \\
\hline $\begin{array}{l}W Q I=\frac{\sum Q_{\mathrm{i}} W_{\mathrm{i}}}{\sum W_{\mathrm{i}}} \\
W_{\mathrm{i}}=\frac{K}{V_{\mathrm{si}}} \\
K=1 / \sum\left(1 / V_{\mathrm{si}}\right) \\
Q_{\mathrm{i}}=\left\lfloor\frac{C_{\mathrm{i}}}{V_{\mathrm{si}}}\right]\end{array}$ & $\begin{array}{l}\text { WQI: water quality index } \\
\text { Qi: quality rating } \\
\text { Wi: relative weight } \\
\mathrm{K}: \text { proportionality constant } \\
V_{\mathrm{si}}: \text { standard value. } \\
C_{\mathrm{i}}: \text { measured value. }\end{array}$ & $\begin{array}{l}\text { WQI }<50 \text { : Excellent. } 0<\text { WQI }<100 \text { :Good } \\
100<\text { WQI }<200: \text { Poor } \\
200<\text { WQI }<300 \text { :Very poor } \\
\text { WQI }>300: \text { Unsuitable }\end{array}$ & $\begin{array}{l}\text { Cude (2001), Al-Obaidy et al. } \\
\text { (2016b), Ramakrishnaiah et al. } \\
\text { (2009) }\end{array}$ \\
\hline $\mathrm{PI}=\frac{\sqrt{\left(\frac{c_{\mathrm{i}}}{s_{\mathrm{i}}}\right)_{\max }^{2}+\left(\frac{c_{\mathrm{i}}}{s_{\mathrm{i}}}\right)_{\text {min }}^{2}}}{2}$ & $\begin{array}{l}\text { PI: pollution index } \\
\text { Ci: measured value } \\
\text { Si: standard value }\end{array}$ & $\begin{array}{l}\mathrm{PI}<\text { : no effect } \\
1<\mathrm{PI}<2 \text { : slightly affected } \\
2<\mathrm{PI}<3 \text { : moderately affected } \\
3<\mathrm{PI}<5 \text { : strongly affected } \\
\mathrm{PI}>5 \text { : seriously affected }\end{array}$ & Caerio et al. (2005) \\
\hline $\mathrm{MI}=\sum_{\mathrm{i}=1}^{\mathrm{n}} \frac{\mathrm{C}_{\mathrm{i}}}{(\mathrm{MAC})}$ & $\begin{array}{l}\text { MI: metal index } \\
\text { Ci: measured value } \\
\text { MAC: max. allowable concen }\end{array}$ & MI $>1$ : is a threshold of warning & Tamasi and Cini (2004) \\
\hline
\end{tabular}


Table 3 Iraqi stream standard for heavy metals (Ministry of Environment 2001)

\begin{tabular}{ll}
\hline Element & $\begin{array}{l}\text { Iraqi stand- } \\
\text { ard (mg/L) }\end{array}$ \\
\hline $\mathrm{Cd}$ & 0.005 \\
$\mathrm{Cr}$ & 0.05 \\
$\mathrm{Cu}$ & 0.05 \\
$\mathrm{Ni}$ & 0.1 \\
$\mathrm{Mn}$ & 0.1 \\
$\mathrm{~Pb}$ & 0.05 \\
$\mathrm{Fe}$ & 0.3 \\
$\mathrm{Zn}$ & 0.5 \\
$\mathrm{Ag}$ & 0.01 \\
$\mathrm{Cn}$ & 0.02 \\
\hline
\end{tabular}

Table 4 Statistical summary of Diyala River's heavy metals

\begin{tabular}{lllll}
\hline Parameter & Min & Max & Mean & Standard Deviation \\
\hline $\mathrm{Cd}$ & 0.0928 & 0.0005 & 0.0334 & \pm 0.0256 \\
$\mathrm{Cr}$ & 1.3181 & 0.0000 & 0.1528 & \pm 0.2084 \\
$\mathrm{Cu}$ & 0.2165 & 0.0000 & 0.1204 & \pm 0.0628 \\
$\mathrm{Ni}$ & 0.6003 & 0.0000 & 0.2543 & \pm 0.1725 \\
$\mathrm{Mn}$ & 0.5623 & 0.0000 & 0.2313 & \pm 0.1508 \\
$\mathrm{~Pb}$ & 1.8202 & 0.1044 & 0.7875 & \pm 0.4188 \\
$\mathrm{Fe}$ & 1.2102 & 0.3163 & 0.6766 & \pm 0.3364 \\
$\mathrm{Zn}$ & 5.9384 & 0.0204 & 2.9515 & \pm 2.7981 \\
$\mathrm{Ag}$ & 0.0075 & 0.0000 & 0.0013 & \pm 0.0028 \\
\hline
\end{tabular}

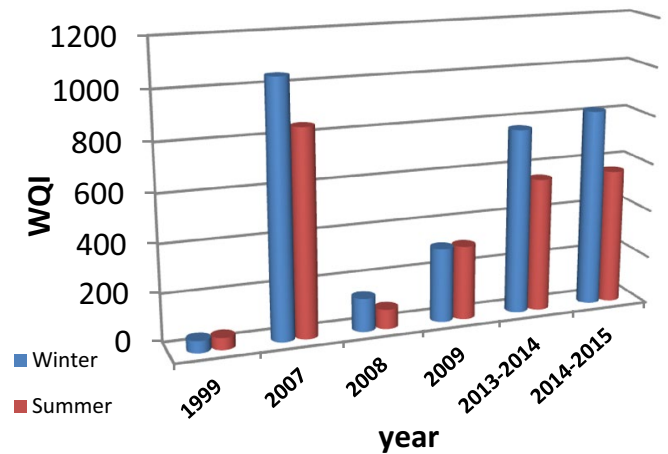

Fig. 2 Historical changes in the WQI of Diyala River

Table 5 The historical evaluation of WQI of Diyala River

\begin{tabular}{llll}
\hline Year & \multicolumn{2}{l}{ WQI evaluation } & Reference \\
\cline { 2 - 3 } & Winter & Summer & \\
\hline 1999 & Excellent & Excellent & Mohammed (1999) \\
2007 & Unsuitable & Unsuitable & Al-Ghabban (2010) \\
2008 & Poor & Good & Musa (2009) \\
2009 & Unsuitable & Unsuitable & Al-Anbari and Jumaa (2010) \\
$2013-2014$ & Unsuitable & Unsuitable & Al-Sudani (2014) \\
$2014-2015$ & Unsuitable & Unsuitable & The present study
\end{tabular}

while Table 7 represents the effect of each element on the river reach (PI). Finally, Fig. 3 depicts the MI for the river reach along the years.

Figure 2 shows an excellent evaluation for the heavy metal WQI during 1999 followed by a rapid declination at 2007, where the WQI reaches its highest levels. WQI in the year of 2008 gives a good WQI then it gets worse through the years 2009-2015 (Table 5). This trend of ups and downs in the WQI can be attributed to the fact that Diyala River, at the reach of interest, was flushed with high quantities of water releases from the upstream Hamrin Dam during 2008 (Ministry of Water resources 2015) as an attempt to washout the accumulated contaminants in the river reach. This process led to the decrease of WQI during 2008, but, and since the upstream water releases was not repeated, due to its bad influence on the downstream receiving Tigris River, the WQI collapsed once again throughout the following years.

As for the seasonal difference in the WQI for the same year (Fig. 2 and Table 6), the higher WQI during winter can be explained due to the presence of excess rainfalls during winter that leads to the washout of the drainage area that contains local electric generators, among others, which produce large amounts of contaminant, especially heavy metals. Some of the wastes produced by the generators are directed into the sewer network reaching Al-Rustimiyah WWTPs, in which there are no heavy metal treatment units and by that the heavy metals are directed into Diyala River with the WWTPs effluents. The second part of generator wastes are spilled on the surrounding land being washed out with rain and reaching Diyala River as well. The contribution of Al-Rustimiyah WWTPs with heavy metals to Diyala River is obvious, since the upstream site (number 1) has a lower WQI than the other sites that are located downstream the effluents of the WWTPs, as shown in Table 6 .

The same historical trend was found for the MI during the years (Fig. 3) which confirms the consistency of the WQI. The MI was found to be a threshold of warning during all years but with different levels.

From the evaluation of the PI shown in Table 7, it was found that $\mathrm{Cd}, \mathrm{Cr}$, and $\mathrm{Pb}$ were the most affecting elements all over the years, as $\mathrm{Pb}$ is one of the side products of the electric generators mentioned before.

\section{Conclusions}

It can be concluded from this study that the water quality status of the last reach of Diyala River has suffered a greet deficiency during the last few decades having 2007 as the peak of heavy metals contamination. The year 2008 shows a recovery of the water quality followed by a rapid declination throughout 2009-2015. Al-Rustimiyah WWTPs increases the lack in the WQI due to the absence of heavy 
Table 6 WQI throughout the river reach for the present study

\begin{tabular}{llllllllrr}
\hline Site No. & 1 & 2 & 3 & 4 & 5 & 6 & 7 & 8 & 9 \\
\hline Winter & 506 & 684 & 830 & 720 & 800 & 893 & 892 & 1051 & 1008 \\
Summer & 264 & 358 & 421 & 429 & 469 & 450 & 490 & 535 & 560 \\
\hline
\end{tabular}

Table 7 PI evaluation of each element throughout the years

\begin{tabular}{lllllll}
\hline Metals & 1999 & 2007 & 2008 & 2009 & $2013-2014$ & $2014-2015$ \\
\hline $\mathrm{Cd}$ & - & - & No effect & Strongly effected & - & Seriously effected \\
$\mathrm{Cr}$ & - & Seriously effected & - & No effect & Seriously effected & Seriously effected \\
$\mathrm{Cu}$ & - & - & No effect & No effect & Seriously effected & Moderately effected \\
$\mathrm{Ni}$ & - & - & - & No effect & - & Moderately effected \\
$\mathrm{Mn}$ & no effect & - & - & No effect & Seriously effected & Moderately effected \\
$\mathrm{Pb}$ & Slightly effected & - & Strongly effected & No effect & - & Seriously effected \\
$\mathrm{Fe}$ & No effect & No effect & - & - & Strongly effected & Moderately effected \\
$\mathrm{Zn}$ & No effect & - & No effect & No effect & - & Seriously effected \\
$\mathrm{Ag}$ & - & - & - & - & - & No effect \\
$\mathrm{Cn}$ & - & Seriously effected & - & - & - & - \\
\hline
\end{tabular}

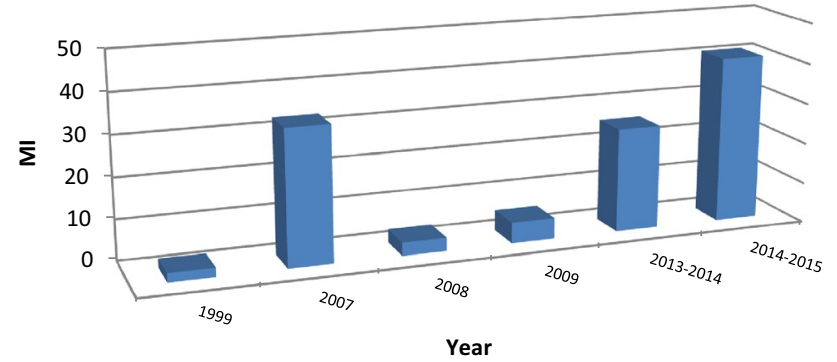

Fig. 3 Historical changes in the MI of Diyala River

metal treatment units. It is proven from the status of river water that it has been unsuitable for human uses for more than two decades.

Open Access This article is distributed under the terms of the Creative Commons Attribution 4.0 International License (http://creativeco mmons.org/licenses/by/4.0/), which permits unrestricted use, distribution, and reproduction in any medium, provided you give appropriate credit to the original author(s) and the source, provide a link to the Creative Commons license, and indicate if changes were made.

\section{References}

Abbasi T, Abbasi SA (2012) Water quality indices. Elsevier, Amsterdam, p 384

Abdulla EJ (2013) Evaluation of surface water quality indices for heavy metals of Diyala River-Iraq. J Nat Sci Res 3(8):63-69

Akoto O, Bruce TN, Darko G (2008) Heavy metals pollution profiles in streams serving the Owabi reservoir. Afr J Environ Sci Technol 2(11):354-359
AL-Anbari RH, Jumaa GF (2010) The evaluation of heavy metals pollution in agricultural lands in Jisser Diyala district. Iraqi J Market Res Consum Prot 2(3):104-116

Al-Ghabban MMJ (2010) Environmental Auditing of Rustimiyah Wastewater Treatment plant Effluents Based on the World Bank Requirements using Remote Sensing Technology. Dissertation, Department of Building and Construction Engineering, University of Technology, Iraq

Al-Haidarey MJS, Hassan FM, Al-Kubaisey ARA, Douabul AAZ (2010) The geoaccumulation index of some heavy metals in AlHawizeh Marsh, Iraq. E-J Chem 7(S1):S157-S162

Al-Hussaini SNH (2016) Suggested improvement techniques for Diyala river water opposite Al-Rustimiyah sewage treatment plants. Dissertation, Department of Building and Construction Engineering, University of Technology, Iraq

Al-Hussaini SNH, Al-Samawi AA (2017) Determination of the biological kinetics for Diyala River at AL-Rustimiyah WWTP's. Iraqi J Civil Eng 11:65-71

Alobaidy AHMJ, Abid HS, Maulood BK (2010) Application of water quality index for assessment of Dokan lake ecosystem, Kurdistan region, Iraq. J Water Res Prot 2:792-798

Al-Obaidy AHMJ, Al-Janabi ZZ, Al-Mashhady AAM (2016a) Distribution of some heavy metals in sediments and water in Tigris river. J Glob Ecol Environ 4(3):140-146

Al-Obaidy AHM, Awad ES, Zahraw Z (2016b) Impact of Medical City and Al-Rasheed power plant effluents on the water quality index value of Tigris River at Baghdad city. In: 2nd Conference on Environment and Sustainable Development 28-29 Oct. Engineering and Techology Journal 34A (4):715-724

Al-Saboonchi A, Mohamed ARM, Alobaidy AHMJ, Abid HS, Maulood BK (2011) On the current and restoration conditions of the southern Iraqi Marshes: application of the CCME WQI on East Hammar Marsh. J Environ Prot 2:316-322

Al-Samawi AA, Al- Hussaini SN (2015) Pollution Status Analysis of Diyala River, Baghdad, Iraq. In: The 2nd International Conference of Buildings, Construction and Environmental Engineering, BCEE2 
Al-Samawi AA, Al- Hussaini SN (2016a) The oxidation reduction potential distribution along Diyala river within Baghdad city. Mesop Environ J 2(4):54-66

Al-Samawi AA, Al- Hussaini SN (2016b) Nitrogen compounds distribution in Diyala River opposite Al-Rustimiyah sewage treatment plants. Eng Tech J 34A(15):2971-2981

Al-Shhrbly QMH (1986) The average daily maximum discharges of the rivers Diyala, Tigris, and euphrates at selected locations. The Ministry of Irrigation/General Corporation for Maintenance and Operation of Irrigation Projects, In Arabic

Al-Sudani HAA (2014) Two Dimensional Mathematical Model of Contamination Distribution in the Lower Reach of Diyala River. M.Sc. Thesis, Department of Environmental Engineering, AlMustansiriyah University, Iraq

APHA (American Public Health Association) (2012) Standard Methods for the Examination of Water and Wastewater. 22st edition Washington DC, USA

Caerio S, Costa MH, Ramos TB, Fernandes F, Silveira N, Coimbra A, Mederios G, Painho M (2005) Assessing heavy metal contamination in Sado estuary sediment: an index analysis approach. Ecol Ind 5(2):151-169

Chougule MB, Wasif AI, Naik VR (2009) Assessment of water quality index (WQI) for monitoring pollution of river Panchganga at Ichalkaranji. In: Proceedings of International Conference on Energy and Environment, Chandigarh pp. 122-127

Cude C (2001) Oregon water quality index: a tool for evaluating water quality management effectiveness. J Am Water Resour Assoc $37: 125-137$

Dede OT, Telc IT, Aral MM (2013) The use of water quality index models for the evaluation of surface water quality: a case study for Kirmir Basin, Ankara, Turkey. Water Qual Expo Health $5(1): 41-56$

Ewaid SH, Abed SA (2017) Water quality index for Al-Gharraf river, southern Iraq. Egypt J Aquat Res 43(2):117-122

Image GE (2017) Data SIO, NOAA, U.S. Navy, NGA, GEBCO, Image Landsat, Google Earth Image. I. Landsat

Lumb A, Sharma TC, Bibeault JF (2011) A Review of genesis and evolution of water quality index (WQI) and some future directions. Water Qual Expo Health 3(1):11-24

Mac-Farlane GR, Schreider M, Mclennan B (2006) Biomarkers of heavy metals contamination in the red fingered marsh carb, Parasesarma erythodactyla. Arch Environ Contam Toxicol 51(4):584-593
Manoj K, Padhy P, Chaudhury S (2012) Study of heavy metal contamination of the river water through index analysis approach and environ metrics. Bull Environ Pharmacol Life Sci 1(10):7-15

Ministry of Environment (MOE) (2001) Iraqi Legislation Preservation of Water Sources Number 2, (A-1)

Ministry of Water Resources, Baghdad, Iraq (2015) special interview

Mohammed FH (1985) Effect of Rustamiyah Treatment Plants Effluents on Diyala River Sanitation. M.Sc. Thesis, Irrigation and Drainage Engineering, University of Baghdad, Iraq

Mohammed MT (1999) Pollution in Diyala River and its Effct on Tigris River by Using Remote Sencing Technique. M.Sc. Thesis, Department of Building and Construction, Technology University, Iraq, in Arabic

Musa SA (2009) Effect of Rustimiyah treatment plant effluent on concentration of some heavy metals in water and sediment of Diyala River. Al-Haitham J Pure Appl Sci 22(3):9

Prasad B, Kumari S (2008) Heavy metal pollution index of ground water of an abandoned open cast mine filled with fly ash: a case study. Mine Water Environ 27(4):265-267

Ramakrishnaiah CR, Sadashivaiah C, Ranganna G (2009) Assessment of water quality index for the ground water in Tumkur Taluk. E-J Chem 6(2):523-530

Reza R, Singh G (2010) Heavy metal contamination and its indexing approach for river water. Int J Environ Sci Technol 7(4):785-792

Shakir E, Al-Mashhady AAM, Al-Janab ZZ, Al-Obaidy AHMJ (2016) Geochemical and geo-statistical assessment of heavy metals concentration in sediment of Shatt Al-Basrah, Iraq. J Basic Appl Res Int 18(4):233-239

Shakir E, Zahraw Z, Al-Obaidy AHM (2017) Environmental and health risks associated with reuse of wastewater for irrigation. Egypt $\mathrm{J}$ Petrol 26(1):95-102

Tamasi G, Cini R (2004) Heavy metals in drinking waters from Mount Amiata (Tuscany, Italy) Possible risks from arsenic for public health in the province of Siena. Sci Total Environ 327(1-3):41-51

Publisher's Note Springer Nature remains neutral with regard to jurisdictional claims in published maps and institutional affiliations. 